\title{
中国庭園における水景技法
}

\section{Technique of the Water scenery in Chinese garden}

\section{河原 武敏 \\ Taketoshi KAWAHARA}

Keyword s：1. 技法

2. 水景

3. 中国庭園

1. Technique

2 . Water scenery 3 . Chinese garden

\section{はじめに}

中国の庭園で水景は築山·建築·植栽とと もに四大施設に数えられている。それは自 然界に存在するその千差万別な地貌の中か ら、その美しい景観を庭園に採りこんだも ので、その技法を「理水」と称している。 本文ではこれを「水景技法」として、諸文 献と実例の中からその基本的な考え方、計 画、施設、施工を明らかにする。

\section{I。水景に関する基本的な考え方}

1、水は山に従って転ず [山因水活 水

\section{随山転]}

中国では古来、「水」の美しさを好み、庭 園の水景技法として用いられている。その 理由を宋の郭熙は「山は水を以って血液と なし、草木を以って毛髪となし、煙霧を以 って風采となす。故に山は水を得て生き、 草木を以って華やかになり、煙霧を以って 秀眉。水は山を以って面とし、亭榭を以っ て眉目となし、釣を楽しむ。故に水は山を 得て媚、亭榭を得て明快、釣りを楽しむ。 此れ山水を配置する所以なり《林泉高致》。」 とし、更に,明の王世貞も作庭するにあたっ て「山には水がめぐる、山は水を得て生き る。故に造園するには先ず池を掘り、その 土で山を築く。池はなるべく広く、山なる ベく高くし《拿山園記》。とあって、山水
の結合で様々な境地を作り出すことができ るからである。

\section{2. 知者は水を楽しむ〔知者楽水 仁} 者楽山]

水景鑑賞の根底には孔子の自然山水に対 する想いが影響している。「智者は水を楽し む、仁者は山を楽しむ。智者は動き、仁者は 静か。智者は楽しみ、仁者は寿ぐ《論語・ 雍也》。」とあるのがそれで。此れに就いて 漢の韓嬰は「水は理に基づいて行われ、小 さな隙間も残さない。一万事平らかで 物を正しく見せる。此れが知者の水を楽し む所以である《韓詩外伝》。」とし、また宋 の朱喜も水が「知者は事を為すのと、流れ が停滞しないのとがにているため、水が楽 しまれるのである《注解》。ととの解説し ている。

\section{3. 庭園は水なくして成立し㩲い〔造園} 必須有水 䇼水難以成園]

庭園造景に「水」の持つ清浄感、開放感、 幽深感、水面の変幻などが要求されている。 清の尤侗は水景の審美的効果を「清らかに 澄んだ「潔」、水面投影の「虚」、音の響く

「動」、水紋の輝く彩りの「文」」の 4 文字 に総括し、明の跑迪は「庭園の優れている のは山と水の二つが備わって居るからで、 水無くして山が有り、山が無くして水が有 るのは優れていると言えない。《愚公谷乗》」 
とか、王世貞も「およそ山を置くに水の無 いのを憎む、《安氏西林記》」とある。

\section{4.人工も自然らしく〔雖由人作、宛自} 天開]

庭園は「人が作ったにせよ、自然らしく 見せるため、なるべく人工の痕跡を残さな いよう工夫することが大切である」と、明 の計成は《園冶・園説》の冒頭で力説して いる。

自然の法則に倣い、庭園施設の自然性を 高めるには、中途半端な模做や濃縮は避け るべきで庭園施設共通の原理としている。

\section{II。水景の計画}

水景には他の施設に無い独自の魅力があ る。それは水態の静かで爽やかな開放感、 動く気勢の变化、水面の投影や音響に意外 な境地にある。

これらの計画について、清の潘来は「水 を留めるに堤を以ってし、流すに渠、平水 面に潭、曲折する所に澗、激しく奔るには 泉、曲がって停滞するところには塘や沼に する《従棹園記》。」と自然に倣うことを強 調し、計成は「高い所は更に高く、低い所 は更に深くす心゙きである《園治》。」と土量 均衡の原則を示唆している。また曹林娣は 計画に「分・隔・破・繞・掩・映 - 近 - 静 声・活《中国園林芸術論》。」という 10 の 変化を示しているが、筆者はこれを水面の 分集・隠現・静動の 3 原則に整理した。

1。池面の大は分け,小は集める〔大 分小聚]

天然の大きな水面は、その広すぎる単調 さを避けるため分割して、大小、長短、深 浅、曲折などの異なる景区を造り、その景 観化を図かっている。その長堤には様々な
様式の橋や亭廊を設けて水面を分割し、空 間に奥行きを与えている。例えば堤によっ て杭州の西湖は 3 分割、揚州の瘦西湖は橋 で2分割してその水景美を高めている。

\section{2. 池面の岸は屈折させる〔貴在曲} 折了

単調な池形は平凡な水景となり奥行感を 損なう。このことを陳従周は「水は深いだ けでなく，曲折の妙が大切である《説園》」 1）と変化をつけるよう強調し、その趣き を生むため章菜烈は《中国園林芸術通論》 に「蔵源」「引流」「集散」の3つを紹介し ている。

(1)藏源 : 水源を滝・洞窟・石の隙間など に隠す方法。水源を探る興味を引き起こす。 例えば蘇州にある環秀山荘の水源は洞硁中 から、獅子林では小赤壁水門、楊州の小盤 谷もまた水源を「雪在山泉」に隠している。 この着想は既に宋代の郭熙が画の中に「遠 くから流れが欲しいなら、流れが断続する ように見せる《林泉高致》。」からと思われ る。

(2)引流 : 水を導いて池面に展開させると き優美な曲線を描いて引き込む方法。例え ば南京の瞻園は滝から曲がりくねつた溪流 と谷澗を経て池に通じ、奥行き感を与えて いる。

(3)集散 : 水面を集散させ、その出入りに よって景観を美しく展開させる方法。これ によって遠近感を増し単調さを避けること が出来る。例えば無錫の寄暢園の池は単調 な方形だが橋廊の出入によって救われてい る。

3. 水面の静態と動態を生尀す〔動水 と静水]

（1）静態水 [静水]） 
水体の色は地味だが、時には豊富な色彩 を生む。中でも静けさが尊重さる池にあっ ては、周囲の景色が水面に映える投影美と 水藻や魚影、雨滴や微風の水紋、水面に映 る月や雲の影、日の輝きなどの反映美など がことのほか喜ばれている。

(1)岸周辺の投影美 : 建築は水面と組み 合わせることによって格別な貼水美を発揮 する。計成は「水の利用については、園の 基盤を水面近くに選定すべきである《園 治》。」と水面と建築の結びつきの効果を示 唆している。これによって生まれる反映美 は既に 1500 年前、北魏の楊街之によって 「青々とした林が水面に垂れ、その緑なす 水はまるで水紋のよう《洛陽伽藍記》。」と 示され、また北周 81）の㣎信は「池の水影 は景勝の地にも勝る《春譜》っとしており、 明末清初の計成もまた「池の鏡に映る白綟 の布 (滝)、園外にめぐる山並みは緑の屏の よう《園冶》。」と周囲の投影美を讃えてい る。清の乾隆帝が承徳の避暑山荘で詠んだ 詩「四面清らかで鏡のように平ら、二層の 楼閣が水面に筧えて画のよう。湖に影を宿 すに良い所《水閘放船至影湖楼》」とあるの は建築色彩の投影を詠ったものである。

(2)不時の投影美 : 不時の気像変化によ つて生まれる水面の投影美に天光雲影、日 昇日落、降雨落雪・激月招雲などがある。 この種の美しさを記したものは数多く、中 でも鎮江の「影園」を描写した《揚州画舫 録》には「園の柳影、水影山影によってこ の名がある」と記され園名の由来を述べて いる。蘇州同里の「退思園」もまた建物が 水面に貼りついた様に見えるので貼水園・ 依水園の別称がある。

（2）動態水 [動水]
激流・瀑布・泉水など水の動きと水音が 尊重されている。中でも水の反響音を楽し む工夫が数多く、有名なものに無錫の:寄暢 園「八音澗」の澗流がある。澗の中で発す る水音が澗道に反響し「八音斉奏」と言わ れている。そのほか北京北海公園の濠㴨澗、 杭州の虎咆泉「水楽」。また滝には蘇州の獅 子林の雨水を建物の軒から築山上の水槽に 集めて落水させ、滝音を観賞する「飛瀑亭小、 環秀山荘の降雨を屋根で集めて滝としたも のもある。

ほかに動態水の効果として観魚施設が数 多く設けられている。蘇州の滄浪亭の「観 魚処小、承徳避暑山荘の “石磯観魚” “知魚 磯”。無錫の:寄暢園の「知魚欄」、上海豫園 の「魚楽榭」、杭州西湖の「花港観魚」など それである。

\section{4. 先ず水源を骎ねる[先在尋源]}

庭園に活きた水が得られないと良い計画 は樹てられない。昔から「一潭死水」は禁 忌とされている。陳従周は「山には脈あっ て貴く、水は源があって貴い。脈理が貫通 すれば全園が生き生きする《説園》。」とそ の水脈の存在を重視し、宋の郭熙もまた「水 は天地の血なり。貴き血は周流し、停滞し ない《林泉高致》。」強調している。清の潘 朱未は園居で最も難しいのは水を得るこ とで、造園の難しさは患うことなく水が得 られることである《縦棹園記》。」と水源獲 得の難しさを嘆いている。

また流れは停滞させぬことが必要である。 計成は「敷地を定めるには先ず水源を確か め水口と出口を疎通させ、その流れ方を考 虑す心゙きである《園治》。」と説きているが、 その水質浄化は容易でない。蘇州の諸庭園 では河道が最近数多く埋め立てられ、停滞 
水を生じて問題となっている。その対策に (1)池底に井戸を掘り移動する地下水と通じ て補給する方法。(2)魚を飼って水中の微生 物を捕食させ、腐敗を防止させる方法があ るものの、質の豊栄養化が進み水性植物の 過度な繁茂の原因になっている。

\section{III。水景の施設}

中国の自然景観は《中国地貌図集》によ ると、構造地貌・流水地貌・カルス卜地貌・ 氷河地貌・風成地貌・黄土地貌・海岸地貌・ 人工地貌・山地と平原に分類されているが、 庭園の水景景観として曹林娣は《中国園林 芸術論》に池塘・湖泊・江河 - 山渓と谷澗 㴚誉・瀑布・淵潭・天池・源泉としている。 本文はこれを池・流れ・滝・庭橋・井泉と 閘門・噴水に分類してその特徵を明らかに する。

1. 池

\section{（1）庭園の規模による特徴}

庭院や小庭園では岸辺に山石や植栽を添 え、水面の彩りに魚が飼育される。小院や 寺院には整形池が用いられ、雨水だまりの 「長方池小、孔廟に倣う書院の「泽池小、風 水説に関倸する「半月池」などがそれであ る。小中庭園では家屋に接してやや細長い 池を配し、橋を架けて水面を釣合よく分割 し奥行き感を作り出す。中大庭園では地岸 を仮山・建築・植栽などにとって総合計画 され、集合分散の原則が用いられる。蘇州 の庭園群は立地条件から横長の長方形池が 造られるので、橋や廊などで中近景を作く り、長手の方向から奥行きある水景を観賞 している。大庭園では池塘や湖沼風が多く 利用され、地勢にならい水面を景区に分割 している。池塘には広々とした「集」と分
散して奥行きを見せる「分」とが用いられ る。堤には整形式の石積み護岸が多く、水 性植物と養魚などして山野の野趣を再現さ せる。湖沼の岸は自然なカーブを描き、堤 で水面を大小に分割し、主景となる島や建 筑を配置する。また景点には州浜・湾・半 島・島・橋などがあり、水源は渓澗や流れ で隠して奥行感を与え、水位は高いと軽快 な感じとなる。北京の願和園昆明湖と万寿 山仏香閣、北海公園の珼華島と白塔がその 例である。

\section{（2）筑山と関保する山石池と池山}

計成はその著《園冶》に「山石池」と「池 山」を紹介している。前者湖石護岸を水 面に張り出して水際を見えなくなるように、 また後者は池の中に仮山を築いて水景と山 景を組み合わせ水仮山と称し、「池の上に山 を築けば園内第一の景勝地となる。山に大 小あれば更に妙景ができる。水面には沢飛 び石 [歩石]、山頂には反り橋を架け、山中 に洞を潜め、或は石を穿ち水を渡るように する。しかも峰巒が微かに遠く見え、雲招 き月隠れる。このような処に仙人が住むの である《園治》。と解説している。南京の 瞻園がこの好例である。

\section{（3）池岸と池面の配植}

池岸植栽はその樹形と色彩によって体形 の異なる臨水建築を引き立てる。一般にや や大きな落葉樹を主木として低い花木と常 緑樹が添えられ、岸辺の枝葉は框景を作る。 池岸の高い場合は枝垂れ柳など、石面には 薜荔などを植え、岸上には营草・玉筧・胡 蝶花・鳳仙花・白丁花・秋海棠などを配し て色彩美を作り出す。水性植物の主なもの は蓮〔荷花〕で、宋の周敦顧による「污れ た泥土から清い花の咲くさまが、まるで污 
れた世の污れに染まらぬよう《愛蓮説》」 という寓意によって大いに普及され、承徳 避暑山荘の “曲水荷花” “遠近泉声”。蘇州 拙政園の清い香が満ちる「遠香堂」。獅子林 の「荷花庁」などがその例。

\section{2。流れ}

\section{(1) 山渓}

谷川の流れと連山で形成された景象。中 国は一般に雨量が少く谷川の水もまた少な い。庭園に天然の渓流が存在する例はまれ である。水源は遠くに見せ、流れは屈曲さ せ、急流、緩流をまじえ、岸に小道、自然石 で険しく護岸する。水底には硆を敷き、水 位は浅くして遊魚や水草の観賞に便利なよ う造られる。例として北京願和園の諧趣園 にある「清琴峡」、蘇州拙政園西部の溪流、 芸直の南斎少院一帯の溪流がある。

\section{（2）潭と洞}

「潭」は深い淵、「澗」は深い山峡の流れ をいう。計成は「仮山は水の存在あって妙 景となる。もし高所から水が引けないなら 澗嗀を造るべきで、水無くとも深遠な感じ を覚える《園治》。と解説している。ここ でいう「辡」は空堀のこと。有名な無錫の: 寄暢園にある「八音澗」は、長さは約 20 $\mathrm{m}$ 、幅 $2-4 \mathrm{~m}$ 、落差約 $1 \mathrm{~m}$ 崖高は 2-3m n 中 の小流が狭く広く、速く緩く、小滝もあり、 様々な水音が反響して格別な趣を見せてく れる。蘇州留園の「聞木征香軒」脇の渓澗、 網師園の「槃澗」、滄浪亭の仮山西側の「流 玉短潭」もその好例。

\section{（3）嫁灌}

水位が低く狭くて長い水面と山形を組合 した景象。山に挟まれて水が満ちている。 例に蘇州の耦園東部仮山の東側にある狭い

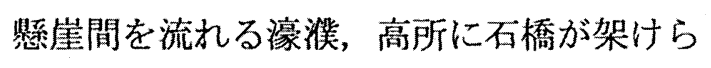

れている。

\section{（4）河流}

流れは不規則な帯状で、時として狭長形 の池になる。河流は長短・直曲・広狭し、 流れる方向を奥行き深いものにさせる。堤 の多くは土岸で自然石を散置し、配植して 野趣に富ませる。一部に仮山・渓谷、亭榭、 船付き場があり、橋を架け、船遊びが行わ れる。例に北京願和園の後湖、揚州の瘦西 湖、蘇州拙政園の東部の曲水、留園西部の 小河などがある。

\section{（5）曲水}

曲水の宴を行うため、水面近く平石を主 にした自然石で護岸し曲流させる方法。「流 杯渠」とも称されている。東晋の 353 年会 稽の蘭亭で王義之が催した曲水の宴が名高 い。彼は「この地は俊嶺な崇山、竹や林が 茂り、清い水が勢いよく流れ左右に映える。 ここで流觞曲水を行った。岸に座り管弦の 音こそ無いが一杯に一詠、心を開いて伸び やかに叙した《蘭亭序》。」とある。上流に 出題する主人が座り、毎回酒盃が各自の前 に流れると一句が要求され、出来ないと罰 杯という宴である。やがて亭と組合した「流 觞亭」が工夫され、宋代の官式造営法規で ある《造営方式》に紹介されている。これ について計成は「昔は曲水を石槽に彫って 造り石の上に龍頭を飾り、その口から水を 噴出しているが工費が高く凡俗である。な ぜ自然の流れにしないのでろうか《園冶》。」 と慨嘆している。

\section{4. 滰[瀑布]}

昔から園内の動水景観として重視されて いる。中国では庭園の立地が平地に多く、 雨量が少ないため渓流の水量はあまり多く ないので低いながら様々に工夫されている。 
一般に雨水を屋根から導いて落水させる方 法【図 1】、または高所の水槽に雨水を溜め、 必要に応じて落下させる方法がある。前者 は蘇州の環秀山荘、後者は獅子林のものが 有名である。

滝の造り方に就いて計成は「瀑布は峭壁 山と同じ方法で造る。先ず高楼の軒から雨 水が利用できるかを調心、雨水を澗で墻の 頂に至らしめて天溝（屋根の雨落ち溝）の ようにし、壁山の頂に至らしめる。そこに 突出た石口から水を噴出させ、溢れ落ちさ せる《園冶》。」と指導している。清代の江 民が楊州の「東園」に造った人工瀑布は「墙 上に木製の水槽を置き、水槽の水門を開け ると、水がほとばしり滝となる。観賞部屋 から俯瞰すると太湖石の数多い裂け目に折 曲しながら深い潭に落ちるのが見える《楊 州画舫録》。」とある。

\section{5 . 庭橋}

庭橋は水面の狭くなった所に架けられ、 一般に数回屈曲させた切石製桁橋が多い。 大水面にはアーチ橋が用いられる。橋高は 小池ほど低く、水に這うようにすると魚影 や水草の鑑賞に便利で更に水面を実際より 広く見せる効果がある。欄干は鉄梱よりも 細長い切石の縁石が環境に調和する。階段 状の石橋は明代伝統様式で、水面の浅い自 然式山石護岸には沢飛び石〔歩石〕が用い られている。

\section{6。泉・井戸と㘓門}

園内の泉は造形加工され動水美観賞の要 所とされる。泉の底には必要あれば粗砂が 敷かれる。天然泉周辺は昔から園地化され、 特に斉南地方の跑突泉は清の乾隆帝により 天下第一泉に指定されている。ほかに鎮江 金山寺にも天下第一泉、無錫の恵山園は天
下第二泉、蘇州虎丘には天下第三泉があり、 庭園では蘇州の環秀山荘の「飛雪泉」。網師 園の「涵碧泉」などはいずれも天然泉水を 整形式の小池に加工されたものである。

井戸は水温が冬暖かく夏冷たいので大事 にされている。池底に水質浄化用の井戸を 掘った例に蘇州の拙政園・留園・獅子林・ 西園・耦園・退思園などがある。

閘門は流量調節の水門で、蕃州獅子林の 池水は複廊南側の暗渠で園外に通じ、北京 匵和園の諧趣園には石橋と一体になった閘 門がある【図 2】。

\section{7 。噴水}

噴き上がる水と音響は庭園に生気を与え る。早くも漢の上林苑には「河水から汲上 げた水を銅製の龍の昍水口から銅仙人が受 け《漢書・典職》。とあり, また唐の長安 にある温泉宮華清池では「薽から出た温泉 が $2 つ の$ 白石で作った蓮に注いだ《毎賈氏 談録》。」とあって共にサイホン現象を利用 したものと思われる。本格的な噴水は 1747 年、清の乾隆帝が円明園に造った西洋楼の 「諧奇趣」「海晏堂」「大法水」で、いずれ も龍尾車(水車)という機械仕掛けである。

\section{IV. 水面護岸施工法}

\section{（1）土坡護岸}

水位が安定し風波穏やかな所に用いられ る。一般に雨水で崩壊し難いよう水面に向 かって緩傾斜をつける。大規模水面に適し、 堤上を植栽することで土坡を固め景観上も 有利である。中には水際崩壊を防ぐため低 く石板を築いた北京の圓明園の例もある 【図 3 】。蘇州拙政園中央部の土坡護岸は莘 が生え、植物がよく繁茂して江南水郷の面 影をよく見せている。明の文徴明が描いた 
《拙政園図》では土謢岸が多く描かれてい るが、現在では雨水の浸食が避けられない ため石護岸が主流である。

（2）石積み護岸：山石で風致的に石積さ れる方法。崩壊防止に有利だが生硬な直線 状と高積みに注意される。角状の黄石や回 凸で水面に変化の作りやすい湖石が多く使 われる。水面が岸内に吸い込まれるよう石 を張出させると広い水面を思わせることが 出来る。

(1)山石護岸 : 用材は自然石でその種類は統 一され、岸の高い所では峭壁式山石護岸、 低い高い所では磯石式山積護岸となってい る。小池の護岸高は $25 \mathrm{c} \mathrm{m}$ から $1 \mathrm{~m}$ 前後が 良いとされる。護岸構造には杭打ち基礎が 必要で護岸石裹込めの磚幅は $50 \mathrm{~cm}$ 前後、 更にその裏込めとして[灰土]を用いる場 合もある【図 4】。杭基礎の上には切石〔条 石または大きな塊石で押さえ、山石は常 水位以下に築き、基礎が水面上に現れない よう注意する。江南の庭園群の多くは山石 護岸、北京願和園の知春亭 - 後湖 - 諧趣園 などの一部にも或る。

また漏水防止法について計成は「薄い板 状の山石を選んで少しでも隙間があると水 は溜まらない。これには “等分平衡法”(力 学上の平衡に留意する方法）を用いる。即 ち石の周辺或は三辺を堅く締める。二辺だ けだと池底の石板が壊れやすく、一辺だけ を圧すると細い裂け目が生じて水を注ぐこ とが出来なくなる。〔灰〕（桐油と石灰を混 ぜた油灰）で塗り固めても水の流失は止ま らない《園治》。」と圧着方法を説いている。 北京北海公園の椱華島山上にある 2 つ方 池の池底と池壁にはセメント混入土[灰土] で固め上に切り石〔条石〕を筑き、目地に
は〔油灰〕を用いている。

(2)磯石護岸 : 断崖の水面近くに置かるるる 低い平地状の石岸。水位の安定しないとき は、低い階段状の磯とする。蘇州にある環 秀山荘の湖石仮山山麓、網師園の彩霞池石 磯は黄石が平積されている。沢飛び石〔汀 石・歩石】が水面の狭く浅い所を渡る橋の 代用として尊重されている。その基礎は素 土をつき固め、[灰土]で二歩打ち固め、上 に比やや大きく平石を $60 \mathrm{~cm}$ の間隔で固 定する。

(3)切石護岸 : 一般に堅質の花崗岩が使用 される。建物や露台の水面に接する部分や 船付き場に多く、形式が単調なので水面局 部に用いられる場合が多い。杭州の《西湖 志》によると、清の 1724 年白堤改修のと き砂を敷いて杭打して陷没を防ぎ〔釷杭貯 土了、石を敷いて切石護岸としたとある。ま た明清以来の宮苑の大池によく使われ、中 でも北京頤和園の昆明瑚東堤は広大な水面 の風波を防ぐため、湖底から高さは 1.7 $2.0 \mathrm{~m}$ 、最高でも $1 \mathrm{~m}$ 前後は水面上に出るよ う計画されている。湖底がへドロと流砂層 の場合は〔梅花杭〕を用い、杭の頭を押さ える切石 [压石]を敷く。築いた切石には 目地モルタルを施し、鋳鉄製の銀錠を石の 継ぎ目に埋め込み、大城磚で裏込めされ【図 51、凍結防止には更にセメント混合土〔灰 土〕を裹込めする【図 6 】。圆明園の「方壼 勝境」で発見された灰土は厚さ約 $1.5 \mathrm{~m}$ も あり、土圧に強いばかりか、厳しい凍結防 止に役立っている。江南地方の庭園では薄 く施すか、使用しない場合もある。杭基材 には柏や杉木が用いられ、杭の配列は〔七 星杭] が多く、基礎地盤や水面の深浅・積 載加重によって変化する。 


\section{おわりに}

中国の水景技法のうち、その基本的な考 え方に目立った相違は無いものの、異なる 風土条件によって施設内容に相違のあるこ とが判明した。その主なものに州浜に代表 される海景がある。このような施設は現存
する庭園にも文献記録にも見当たらないが 2002 年、長安にある唐代大明宮遺跡の太液 池蓬莱岛南岸に川原石敷きが発見されてい る。技術的記録の稀な中国庭園の技法がこ うした発掘調査によって明らかにされるこ とが大いに期待される。以上

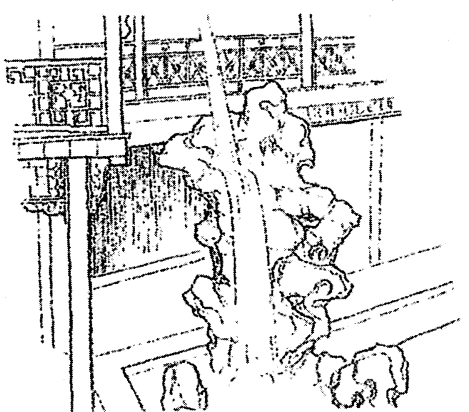

〔図 1〕降雨利用の滝

(蘇州・環秀山荘)

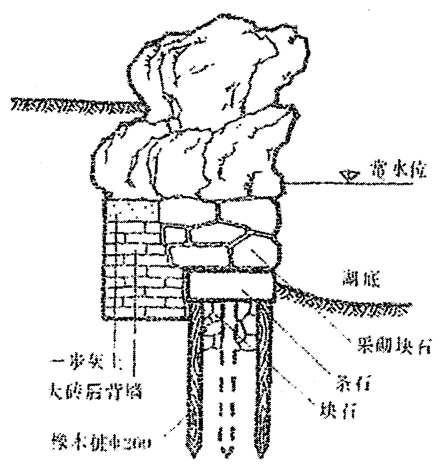

[図 4]山石護岸

（北京·顗和園）

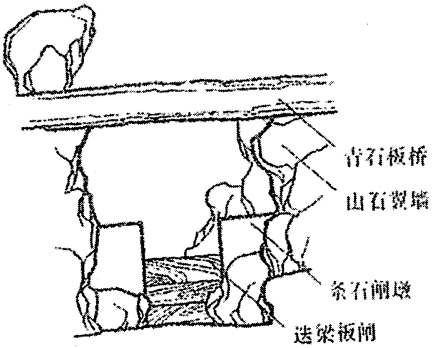

〔図 2〕石橋一体の閙門 （北京・頣和園の諧趣園）

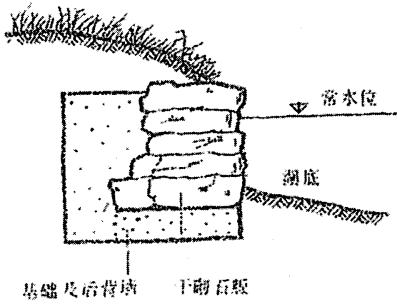

[図 3]土坡護岸 （北京・円明園）

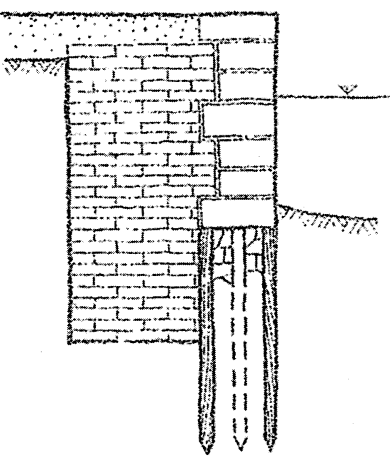

【図 5〕切石護岸-1

(北京・願和園)

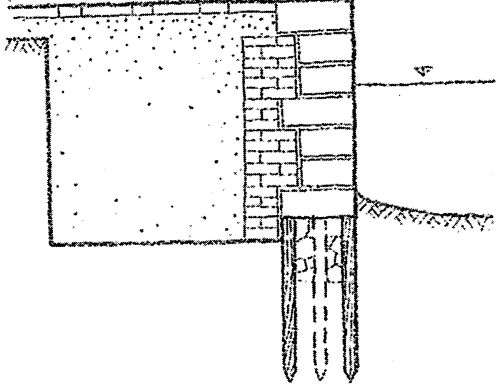

[図 6] 切石護岸-2

（北京・頣和園）

出典 : 図版は中国科学院自然科学史編 : 《中国古代建筑史》科学出版社 1990 加引用

参考文献 1）陳植注釈：《園冶注釈》中国建築工業出版社 1984

2) 中国科学院自然科学史研究所主編：《中国古代建築史》科学出版社 1990

3 ）張承安主編：《中国園林芸術辞典》湖北人民出版社 1994

4) 陳従周著：《説園》同済大学出版会 1986

5 ）張家驥編著 : 《中国園林大辞典》山西教育出版社、1997

6 ）曹林娣著 : 《中国園林芸術論》山西教育出版社 2001

7 ）陳従周主編：《中国園林鑑賞辞典》華東師範大学出版社 2001

8 ）章菜烈編著：《中国園林芸術通論》上海科学出版社 2004 